\title{
PENDIDIKAN AKHLAK SEBAgaI DASAR PEMBENTUKAN KARAKTER DI PONDOK PESANTREN SUKAMANAH TASIKMALAYA
}

\section{MORAL EDUCATION AS A FOUNDATION OF CHARACTER BUILDING IN PONDOK PESANTREN SUKAMANAH, TASIKMALAYA}

\author{
Risa Nopianti \\ Balai Pelestarian Nilai Budaya Bandung \\ Jalan Cinambo No.136 Ujungberung - Bandung 42094 \\ e-mail : risanopianti@gmail.com
}

\begin{abstract}
Abstrak
Pesantren sebagai sebuah lembaga pendidikan keagamaan memiliki visi yang cukup sentral dalam mencerdaskan kehidupan bangsa. Selain mengemban tugas mencerdaskan kognisi peserta didiknya, pesantren juga bertujuan untuk memberikan kecerdasan spiritual dan sosial. Kecerdasan spiritual tersebut salah satunya dibentuk oleh pendidikan akhlakul karimah. Penelitian ini bertujuan untuk mengetahui hubungan pendidikan akhlak dengan pembentukan karakter santri di Pesanten Sukamanah, Tasikmalaya. Penelitian kualitatif dengan perspektif etnografi digunakan untuk memaparkan dan menganalisa data. Pendidikan akhlak memberikan bekal konsep spiritual pada diri seorang santri dalam bersikap dan berperilaku. Adapun salah satu implementasi praktis dari pendidikan akhlak adalah tata tertib dan tatakrama yang merupakan perwujudan dari tata kelakuan dan menjadi bagian dari norma sosial. Tata tertib dan tatakrama berperan penting untuk penanaman nilai-nilai spiritualitas dalam membentuk karakter para santri.
\end{abstract}

Kata kunci: norma, tatakrama, tata kelakuan, pendidikan akhlak, pesantren.

Abstract

Pesantren as a religious education institution has a central vision in the intellectual life of the nation. In addition to carrying out the task of educating students cognition, pesantren also aims to provide spiritual and social intelligence. Spiritual intelligence can be formed by akhlakul karimah education. This study aims to determine the relationship of moral education with the formation of santri (students) characters in Sukamanah pesantren, Tasikmalaya. Qualitative research with an ethnographic perspective is used to describe and analyze data. Moral education has provided a spiritual concept for a santri in behaving and act. As for one of the practical implementations of moral education is the rules and manners which are the embodiment of behavior and become part of social norms. Rules and manners play an important role in the cultivation of spiritual values in shaping the character of the santri.

Keywords: norm, manners, behavior, moral education, character education, boarding schools.

\section{A. PENDAHULUAN}

Pendidikan

karakter

telah

dicanangkan oleh pemerintah dalam hal ini Kementerian Pendidikan dan Kebudayaan sebagai bagian dari pendidikan moral. Konsep ini bertujuan untuk mengimbangi sistem pendidikan di Indonesia yang selama berpuluh-puluh tahun sangat menekankan dimensi pengetahuan dalam melatih kognisi peserta didiknya. Melalui pendidikan karakter diharapkan dapat mencetak generasi muda yang terdidik 
secara keilmuan dan terasah moral dan mentalnya.

Posisi sentral pendidikan karakter dalam sistem pendidikan nasional telah memperoleh kekuatan legal dalam sistem hukum Indonesia. Sebagaimana yang tercantum dalam Pasal 3 Undang-Undang Sistem Pendidikan Nasional yang menyebutkan bahwa "Pendidikan Nasional berfungsi mengembangkan dan membentuk watak serta peradaban bangsa yang bermartabat dalam rangka mencerdaskan kehidupan bangsa, bertujuan untuk berkembangnya potensi peserta didik agar menjadi manusia yang beriman dan bertakwa kepada Tuhan Yang Maha Esa, berakhlak mulia, sehat, berilmu, cakap, kreatif, mandiri, dan menjadi warga negara yang demokratis dan bertanggungjawab" (Simatupang, dkk., 2012: 2). Dalam pengertian lain bahwa pembentukan manusia-manusia yang berilmu dan berakhlak menjadi tanggung jawab sistem pendidikan Indonesia yang harus didorong kemajuan dan implementasinya oleh seluruh masyarakat Indonesia.

Salah satu penekanan output dari pendidikan karakter adalah membentuk manusia yang barakhlak mulia. Sejalan dengan pendidikan karakter, terdapat juga konsep pendidikan akhlak $^{1}$ yang lebih menekankan pada nilai-nilai keagamaan, lebih khusus lagi adalah agama Islam. Melalui pendidikan akhlak anak-anak diarahkan untuk diasah spiritualnya sehingga menjadi pribadi yang mampu mengelola jiwanya supaya senantiasa dapat berbuat baik. Hal ini disebut juga dengan kecerdasan spiritual. Kecerdasan spiritual merupakan tingkat kecerdasan tertinggi yang dapat dimiliki seseorang. Dengan memiliki kecerdasan spiritual orang dapat

\footnotetext{
1 Akhlak adalah bentuk jamak dari "khulq" berasal dari bahasa Arab yang artinya karakter atau sifat. Sedangkan menurut konsepnya, akhlak paling umum diartikan sebagai karakterkarakter atau sifat-sifat yang melekat kuat pada jiwa manusia (Al Musawa, 2016).
}

memaknai hidup, dan menjalankannya secara bijaksana (Utama, 2010).

Kecerdasan spiritual dapat diperoleh seseorang melalui pendidikan formal maupun nonformal. Pendidikan pesantren merupakan salah satu bentuk pendidikan formal bagi seseorang untuk meningkatkan kecederdasan spiritualnya.

Dalam lingkup pendidikan formal kecerdasan spiritual salah satunya diejawantahkan dalam bentuk pendidikan akhlakul karimah. Pendidikan akhlak ini disaripatikan dari Al-Qur'an dan Hadist sebagaimana yang dicontohkan oleh Nabi Muhammad SAW. Melalui pendidikan akhlak peserta didik diberi pengetahuan mengenai bagaimana harus bersikap, bersosialisasi, dan berakhlakul karimah itu sendiri, sehingga mencerminkan sebuah pribadi yang baik.

Selain berfungsi untuk mengasah kepribadian dan menciptakan kecerdasan dalam mengkaji nilai-nilai agama, pendidikan akhlak dalam lingkup formal dapat berfungsi sebagai dasar pembentukan karakter, sebagaimana yang telah diamanatkan Undang-undang Sisdiknas. Pertanyaannya kemudian adalah bagaimana relevansi antara pendidikan akhlak yang didasari oleh kecerdasan spiritual ini dapat memberi dasar-dasar tata kelakuan yang melembaga di lembaga pendidikan agama seperti pesantren sehingga mampu menjadi dasar pembentukan karakter pada diri peserta didiknya?

Kajian-kajian mengenai pendidikan karakter maupun pendidikan akhlak telah banyak ditulis oleh para peneliti yang ada saat ini di antaranya Desi Novitasari (2016) yang meneliti mengenai "Implementasi Pendidikan Karakter Berbasis Al-Qur'an di SD IT Lukman AL Hakim Internasional" menemukan bahwa implementasi pendidikan berbasis AlQuran diterapkan melalui proses pembelajaran dan program-program sekolah. Amri (2014) mengenai 'Pendidikan Karakter Berbasis Al-Qur'an; Upaya Menciptakan Bangsa yang 
Berkarakter" mengatakan untuk mewujudkan pendidikan karakter berbasis Al-Qur'an diperlukan adanya tiga peran penting yaitu 1) peran masyarakat lewat pendalaman akidah dan akhlak Rasulullah, SAW. 2) peran dunia pendidikan lewat sarana sekolah dan masjid, 3) dan peran pemerintah. Munawar (2013) dalam skripsinya berjudul "Pendidikan Karakter dalam Pembelajaran Akidah Akhlak" menyatakan bahwa pendidikan karakter dalam mata pelajaran Akidah Akhlak adalah suatu penyatuan atau penggabungan antara upaya kegiatan membentuk karakter peserta didik dengan mata pelajaran yang memiliki pokok bahasan yang memberi motivasi untuk berakhlakul karimah dalam kehidupan sehari-hari. Dyah Kumalasari (2012) dalam "Pendidikan Karakter Berbasis Agama", menemukan tiga hal penting yaitu 1). Pendidikan akhlak mengedepankan konsep kesederhanaan, kedisiplinan, merdeka, serta akhlak yang mulia, 2). Pendidikan akhlak memberikan keseimbangan kecerdasan intelektual dan spiritual, 3). Iman, ilmu dan amal sebagai dasar agama bukan hanya difahami tetapi juga harus diamalkan. Desi Triwulandari (2015) dalam penelitiannya mengenai "Penerapan Pendidikan Karakter dalam Meningkatkan Akhlak" menemukan bahwa di Homeschooling Group SD Khoiruummah pendidikan karakter diimplementasikan melalui saofah, fiqih nisa, dan tauhid, pemilihan ketua kelas, senam, imam salat, dan pembudayaan senyum dan sapa. Terakhir Mamat Rahmadi (2014) menulis mengenai "Pengelolaan Pendidikan Berbasis Islam", temuannya bahwa sekolah melakukan perencanaan program diawali dengan penetapan visi dan misi, menyusun kurikulum terpadu mengintegrasikan antara kurikulum nasional dan kurikulum khas dengan penekanan pada pendidikan akhlak mulia. Monitoring dan evaluasi dilakukan terus menerus terhadap seluruh aspek kegiatan siswa. Keberhasilan ditandai adanya perubahan perilaku siswa seperti disiplin, rajin ibadah, taat, jujur, berprestasi dan tidak tawuran.

Seluruh penelitian yang telah
dilakukan di atas mencoba mengintegrasikan pendidikan karakter dengan pendidikan akhlak secara formal yang dasarnya berasal dari pengetahuan dan nilai-nilai keagamaan. Implementasi dapat dilakukan dengan berbagai cara yang tujuan utamanya adalah pembentukan karakter, kepribadian siswa yang baik dan berakhlakul kharimah. Namun penulis merasa masih ada celah yang dapat dilengkapi untuk menyempurnakan studistudi tentang pendidikan karakter dan sinkronisasinya dengan pendidikan akhlak, yaitu melalui kebudayaan. Budaya berupa nilai dan norma perwujudannya masih bersifat abstrak seperti halnya nilai-nilai keagamaan yang melekat pada pendidikan akhlak, oleh karenanya implementasi pendidikan akhlak ini perlu dituangkan pada sebuah konsep yang lebih konkret dalam bentuk tatakrama. Hal ini dirasa cukup penting untuk dikaji sebagai salah satu bentuk pengembangan pendidikan karakter yang didasarkan pada agama.

\section{B. METODE PENELITIAN}

Penelitian ini dilakukan menggunakan metode etnografi ${ }^{2}$ dengan pendekatan kualitatif. Untuk memperoleh data-data yang valid mengenai tema penelitian digunakan teknis pengumpulan data berupa wawancara dan observasi lapangan dan partisipasi. Wawancara dilakukan pada guru, santri, dan masyarakat yang tinggal di sekitar Pesantren Sukamanah, sedangkan observasi dilakukan di lingkungan pesantren dan di luar lingkungan pesantren. Adapun partisipasi dilakukan di luar lingkungan pesantren, terutama di rumah-rumah warga sekitar yang

\footnotetext{
${ }^{2}$ Metode etnografi adalah metode khas ilmu antropologi yang mencoba menangkap sudut pandang native mengenai hubungannya dengan kehidupan dan kesadaran visi dan dunianya. (Malinowski dalam Spreadley, 1997).
} 
berkontribusi mendukung sistem pembelajaran di pesantren.

Pemilihan informan dikategorikan menjadi dua bagian yaitu informan kunci dan informan biasa. Informan kunci adalah para pengajar, guru dan ustadz yang memiliki ilmu dalam metode pembelajaran agama khususnya ilmu akhlak sehingga informasi yang berhubungan pengajaran pendidikan akhlak dapat digali secara optimal. Kategori informan biasa adalah para santri dan masyarakat di sekitar pesantren. Penggalian informasi dari mereka dilakukan untuk mengetahui implementasi penerapan pendidikan akhlak terhadap para santri dan penilaiannya oleh masyarakat.

\section{Pendidikan Karakter Kaitannya dengan Pendidikan Akhlak}

Menurut Muchlas Samani dan Hariyanto (2013: 41):

"karakter dianggap sebagai nilai-nilai perilaku manusia yang berhubungan dengan Tuhan YME, diri sendiri, sesama manusia, lingkungan, dan kebangsaan yang terwujud dalam pikiran, sikap, perasaan, perkataan, dan perbuatan berdasarkan norma-norma agama, hukum, tatakrama, budaya, adat istiadat dan estetika."

Nilai-nilai yang diharapkan muncul dalam karakter seorang individu harus dilatih dan dididik, supaya menjadi kebiasaan (habit) hingga terbentuk karakter baik yang muncul atas dasar kesadaran dirinya terhadap nilai-nilai kebaikan (Gunawan, 2012: 24). Para pakar setuju bahwa pendidikan formal dapat digunakan sebagai alat dalam upaya meningkatkan karakter. Oleh karenanya kemudian dikenal pendidikan karakter. Di samping itu juga terdapat pendidikan formal yang berbasis pada nilai-nilai agama yang juga bertujuan untuk mengasah karakter dan kepribadian religius seorang anak yang disebut pendidikan akhlak.

Secara formal sebagaimana yang diamanatkan undang-undang pendidikan: "pendidikan karakter bertujuan membentuk karakter bangsa yang tangguh, kompetitif, berakhlak mulia, bermoral, bertoleran, bergotongroyong, berjiwa patriotik, berkembang dinamis, berorientasi ilmu pengetahuan dan teknologi, yang semuanya dijiwai oleh iman dan takwa kepada Tuhan YME berdasarkan Pancasila (Gunawan, 2012: 30)."

Dengan demikian pendidikan karakter yang didasari oleh keimanan dan ketaqwaan dapat menguatkan aspek-aspek psikologis dalam diri seseorang sehingga mampu mencerminkan karakter mereka yang sesungguhnya.

Pendidikan karakter berisi nilai-nilai karakter yang diharapkan dapat terinternalisasi dalam diri peserta didik dan menjadikannya manusia yang memiliki karakter baik. Pendidikan karakter bukanlah suatu materi yang harus dihafal, tapi suatu upaya kegiatan pemberian pemahaman nilai-nilai karakter yang dikembangkan melalui setiap mata pelajaran, pengembangan diri dan budaya sekolah (Munawar, 2013: 34).

Pendidikan karakter memuat berbagai macam bidang ilmu yang ditujukan untuk mengasah kepekaan moral, sosial, dan spiritualnya sehingga dapat membentuk pribadi yang berkarakter. Pribadi berkarakter juga dapat dibentuk secara religius sesuai dengan nilai-nilai islami. Salah satu pelajaran dalam agama Islam yang mendukung pelaksanaan pendidikan karakter adalah pendidikan (akidah) akhlak. Tujuan pembelajaran pendidikan akhlak adalah agar peserta didik memiliki pengetahuan, penghayatan, dan keyakinan yang benar terhadap hal-hal yang harus diimani, sehingga dalam bertingkah laku dan bersikap sehari-hari berdasarkan AlQur'an dan Hadits. Serta memiliki kemauan yang kuat untuk mengamalkan akhlak yang baik dan berusaha untuk meninggalkan akhlak yang buruk, baik dalam hubungannya dengan Allah SWT, diri sendiri, antarsesama manusia atau 
dengan alam lingkungan. (Munawar, 2013: 34).

Pendidikan akhlak pada intinya bertujuan untuk mengasah kepribadian seorang anak supaya memiliki karakter yang baik dengan dasar-dasar pemahaman ilmu agama yang baik sesuai dengan pedoman nilai-nilai islami yang tertuang dengan sangat jelas dalam Al Qur'an dan Al Hadist.

\section{Norma Sosial}

Kata norma berasal dari bahasa Belanda norm, yang berarti pokok kaidah, patokan, atau pedoman. "Norma adalah standar perilaku yang dibuat dan dipertahankan dalam suatu masyarakat. Untuk menjadi signifikan norma harus ditaati dan dimengerti bersama" (Schaefer, 2012: 72). Jadi menurut Schaefer bahwa ketaatan akan norma-norma yang berlaku dalam suatu masyarakat dapat terjadi apabila norma tersebut difahami dengan baik makna dan tujuannya, sehingga perilaku masyarakat akan senantiasa terjaga sesuai kaidah norma yang berlaku.

Norma pada suatu masyarakat memiliki tingkat kekuatan tertentu, ada yang bersifat lemah, sedang, hingga kuat dan mengikat. Norma berdasarkan tingkatannya dapat dibedakan menjadi empat, yaitu : (1) cara (usage) menunjuk kepada sebuah bentuk perbuatan dalam hubungan antarindividu, dan sifatnya sangat lemah ; (2) kebiasaan (folksway) diartikan sebagai perbuatan yang diulangulang dalam bentuk yang sama merupakan bukti bahwa orang banyak menyukai perbuatan tersebut, kebiasaan mempunyai kekuatan yang lebih mengikat daripada cara ; (3) tata kelakuan mencerminkan sifat-sifat yang hidup dari kelompok manusia yang dilaksanakan sebagai alat pengawas, secara sadar maupun tidak sadar, oleh masyarakat terhadap anggotaanggotanya ; (4) adat istiadat (customs) merupakan sebuah tata kelakuan yang bersifat kuat dan kekal serta telah terintegrasi dalam pola-pola perilaku masyarakat (Soekanto, 2013: 174-176).
Berdasarkan sifatnya norma terbagi menjadi norma sosial dan norma moral. Norma sosial bisa bersifat formal maupun informal, yang berbentuk dalam tata aturan atau tata kelakuan. Sedangkan norma moral terdiri dari : 1) norma agama, yaitu ketentuan-ketentuan yang bersumber dari ajaran-ajaran agama yang dianggap sebagai wahyu dari Tuhan yang keberadaannya tidak boleh ditawar-tawar lagi; 2) norma kesopanan, yaitu ketentuanketentuan hidup yang sumbernya dari polapola perilaku sebagai hasil interaksi sosial dalam kehidupan kelompok; 3) norma kesusilaan, yaitu ketentuan-ketentuan kehidupan yang berasal dari hati nurani, produk dari norma susila ini adalah moral; 4) norma hukum, yaitu ketentuanketentuan hidup yang berlaku dalam kehidupan sosial yang sumbernya adalah undang-undang yang dibuat oleh lembaga formal kenegaraan (Setiadi dan Kolip, 2011: 129-133).

Lebih lanjut norma kesopanan yang terbentuk dari hasil interaksi perilakuperilaku sosial diimplementasikan melalui tatakrama. Kata tatakrama berasal dari bahasa Jawa yang berarti aturan yang baik. Tatakrama sebagai bagian dari tata kelakuan yang bersumber pada norma sosial, bersifat memaksa para anggotanya untuk melakukan suatu perbuatan dan di lain pihak melarang perbuatan-perbuatan tertentu ${ }^{3}$. Tatakrama sebagai wujud norma sosial "berorientasi pada aturan-aturan dalam kehidupan sosial secara kolektif, yang mengandung berbagai sanksi" (Setiadi dan Kolip, 2011: 131). Tatakrama merupakan alat ukur yang dibuat untuk menekan anggota masyarakat supaya perilakunya sesuai dengan nilai-nilai dan tata kelakuan yang ada. Konsep tatakrama merujuk pada adab pergaulan yang biasa dilakukan dalam kehidupan sehari-hari. Walaupun konsep ini rentan terhadap perubahan karena adanya perubahan dalam nilai-nilai pergaulan di masyakat, namun

\footnotetext{
${ }^{3}$ Dikutip dari http://www.lintasjari.com/7566/jenis-jenisnorma-sosial/
} 
pada intinya tatakrama akan selalu berpusat pada nilai kepantasan, kebiasaan, serta kepatuhan yang berlaku pada lingkungan di mana mereka mengadaptasikan diri. Oleh sebab itu konsep tatakrama menyangkut pola-pola hubungan sosial baik antara individu dengan individu, maupun antara individu dengan kelompok.

\section{Pesantren}

Istilah pesantren biasa digabungkan dengan kata pondok menjadi pondok pesantren. Meskipun sekilas tampak sama kedua istilah ini (pesantren dan pondok pesantren) mengandung makna yang berbeda. Pesantren merupakan lembaga pendidikan yang melakukan pembelajaran ilmu-ilmu keislaman. Sedangkan kata pondok berasal dari funduq (bahasa Arab) yang artinya ruang tidur, asrama atau wisma sederhana, karena pondok memang diperuntukkan sebagai tempat penampungan sederhana dari para pelajar atau santri yang jauh dari tempat asalnya (Dhofier, 1982: 18). Menurut Manfred Ziemek (1986) kata pesantren berasal dari kata santri yang diimbuhi awalan pe- dan akhiran -an yang berarti menunjukkan tempat, maka artinya adalah tempat para santri. Sedangkan kata santri menurut kamus besar bahasa Indonesia adalah orang yang sedang menuntut ilmu agama.

Dengan demikian pondok pesantren dapat diartikan:

"sebagai suatu lembaga pendidikan agama Islam yang tumbuh serta diakui masyarakat sekitar, dengan sistem asrama di mana santri-santri menerima pendidikan agama melalui sistem pengajaran atau madrasah yang sepenuhnya berada di bawah kedaulatan dari kepemimpinan seseorang atau beberapa orang kiai dengan ciri-ciri khas yang bersifat kharismatik serta independen dalam segala hal (Qomar,2005: 2)."

Adapun tujuan pesantren dapat dilihat dari beberapa dimensi, seperti yang diutarakan oleh Hiroko dalam (Qomar, 2005: 4) yang melihat pesantren dari dimensi otonomi bahwa tujuan pesantren adalah untuk melatih para santri memiliki kemampuan mandiri. Sedangkan menurut Ziemek dalam (Qomar, 2005: 4) tujuan pesantren dilihat dari keterpaduan aspek perilaku dan intelektual adalah membentuk kepribadian, memantapkan akhlak, dan melengkapinya dengan pengetahuan.

Pesantren-pesantren di Indonesia dikelompokkan oleh Kementerian Agama berdasarkan sarana dan prasarana yang tersedia memiliki beberapa variasi bentuk atau model yang secara garis besar di kelompokkan ada tiga tipe.

Pesantren tipe A, yang menetapkan santrinya untuk belajar dan menginap secara khusus di pesantren. Mereka tidak memiliki kurikulum yang jelas hanya berdasarkan pengetahuan spiritual dan empirik para pengajarnya. Pola pembelajaran yang digunakan pada pesantren berupa sorogan, bandongan dan lainnya. Pesantren tipe ini tidak menyelenggarakan pendidikan secara formal di madrasah.

Pesantren tipe B memiliki ciri-ciri di antaranya: para santri tinggal dalam pondok asrama; kurikulum pendidikan merupakan paduan antara pola pembelajaran asli pesantren dengan sistem madrasah/sistem sekolah formal sehingga kurikulumnya jelas; selain masjid juga memiliki tempat khusus yang berfungsi sebagai sekolah/madrasah.

Adapun pesantren tipe $\mathrm{C}$ adalah pesantren yang memisahkan antara pendidikan pesantren dengan pendidikan formal, sehingga pesantren semata-mata hanya menjadi tempat tinggal bagi para santri, karena para santri belajar di madrasah atau sekolah yang letaknya di luar lingkungan dan bukan milik pesantren. Waktu belajar di pesantren biasanya dilakukan setelah santri menyelesaikan jam belajar di sekolah/madrasah (ketika mereka berada di pondok/asrama).

Secara umum sebuah institusi dapat dikatakan sebagai pesantren apabila minimal memiliki tiga unsur penting ini yaitu kiai sebagai pengajar, santri sebagai 
murid, dan masjid sebagai tempat untuk memberikan pengajaran (Shodiq, 2011).

\section{HASIL DAN BAHASAN}

\section{Kehidupan di Pesantren Sukamanah}

Nama resmi Pesantren Sukamanah adalah Pesantren K.H. Zaenal Mustofa. Sukamanah sendiri merupakan nama sebuah daerah atau lebih tepatnya perkampungan di mana pesantren ini berdiri yang masuk ke dalam wilayah administratif Singaparna, Kabupaten Tasikmalaya. Pesantren ini didirikan oleh K.H. Zainal Mustofa ${ }^{4}$ pada tahun 1927 di atas sebidang tanah yang diwakafkan oleh Hj. Siti Juariah. K.H. Zainal Mustofa memimpin pondok pesantren ini selama 17 tahun. Hingga saat ini telah beberapa kali berganti pimpinan dan yang terakhir saat ini dipimpin oleh K.H. A. Tohir Fuad.

Menurut kategorisasi pesantren yang didasarkan pada fasilitas sarana dan prasarana yang ada, Pesantren Sukamanah dapat digolongkan pada pesantren jenis B yaitu pesantren yang memisahkan dengan jelas sistem pendidikan formal dan non formal, namun masih menggunakan metode pembelajaran agama secara tradisional dengan pembelajaran kitabkitab. Atau disebut juga pesantren gabungan salaf dan modern ${ }^{5}$.

${ }^{4}$ K.H. Zainal Mustofa adalah ulama sekaligus pahlawan nasional yang berasal dari Jawa Barat, yang pada masa Pemerintahan Jepang (1944) melakukan perlawanan dengan semangat jihad.

5 Pesantren modern merupakan metode pendidikan pesantren yang mengadopsi kurikulum pendidikan umum yang dikombinasikan dengan pendidikan agama secara formal. Menekankan pada nilai-nilai kemodernan seperti disiplin dan tepat waktu, rajin, berpestasi, serta menguasai ilmu pengetahuan dan teknologi. Ciri selanjutnya adalah penggunaan bahasa asing sebagai pengantar pembelajaran baik itu bahasa Arab maupun bahasa Inggris. Sedangkan pesantren salaf atau tradisional merupakan pesantren yang mengaplikasikan pendidikan agama tradisional dengan mengkaji kitab-kitab kuning dengan sistem sorogan dan wetonan.
Struktur organisasi Pesantren Sukamanah dibagi menjadi dua bagian. Bagian pertama adalah struktur pondok pesantren yang dipimpin langsung oleh K.H. A. Tohir Fuad sebagai pimpinan pesantren yang membawahi bidang pendidikan dan pengajaran, bidang humas, bidang pengembangan sarana, bidang usaha, dan bidang sosial. Boleh dikatakan bahwa struktur organisasi ini bersifat umum karena berhubungan dengan kelembagaan pesantren baik itu hubungannya dengan pesantren itu sendiri maupun dengan masyarakat atau kelembagaan lain di luar pesantren. Struktur kedua adalah struktur organisasi dewan santri yang dipimpin oleh Eka Mulyana, yang membawahi antara lain bidang pendidikan, bidang kedisiplinan dan keterampilan, bidang olah raga, bidang kebersihan, bidang logistik dan komputer, bidang kemasjidan, dan bidang kesenian, serta asrama santri. Struktur organisasi dewan santri lebih spesifik mengatur tata kerja santri dengan pesantren, maupun santri dengan pendidikannya.

Hal ini tentunya berimbas pada padatnya jadwal para santri setiap harinya. Karena selain mereka diharuskan untuk menimba ilmu formal di sekolah umum, mereka juga diwajibkan mengikuti kegiatan pembelajaran keagamaan yang biasanya dilaksanakan setelah sekolah.

Jam belajar santri sangat padat, dimulai pagi hari dari jam 7 pagi hingga pulang sekolah pada pukul setengah 3 yang dilaksanakan di sekolah formal (Madrasah Alliyah Sukamanah). Kemudian mereka pulang ke asramanya masing-masing untuk beristirahat sejenak dilanjutkan dengan salat ashar berjamaah dan mengaji di masjid pesantren. Jeda waktu kurang lebih satu jam menjelang maghrib dimanfaatkan oleh santri untuk istirahat di asrama atau sekitarnya bersama rekan-rekan sesama santri. Baru ketika tiba waktu magrib mereka kembali melaksanakan salat magrib berjamaah di masjid pesantren, yang dilanjutkan kembali dengan kegiatan pengajian rutin yang dibimbing oleh para 
ustadznya hingga pukul 8 malam. Pengajian malam terbagi menjadi dua sesi. Beberapa santri ada yang kemudian melanjutkan pengajian sesi kedua hingga pukul 10 malam, namun ada juga yang langsung beristirahat di asrama. Dini hari pada pukul 03.30-04.00 para santri bangun untuk menunaikan salat tahajud berjamaah bersama para guru dan rekan-rekannya sesama santri, dilanjutkan dengan salat subuh berjamaah. Ba'da subuh sampai pukul 6 pagi diisi kembali dengan kegiatan pengajian. Tersisa waktu selama satu jam untuk para santri sarapan dan bersiap-siap di asramanya masing-masing untuk pergi ke sekolah. Hari jumat kegiatan belajar mengajar di sekolah tetap normal dilakukan, hanya saja kegiatan pengajian di pesantren diliburkan. Waktu libur ini dimanfaatkan oleh santri untuk merefresh energi dan mood nya supaya tidak terlalu jenuh dengan rutinitas sehari-hari mereka. Pada hari Jumat inilah biasanya dilakukan kegiatan kebersihan umum dan olah raga seperti, sepak bola, basket, badminton, volly, dan sebagainya yang dilakukan bersama rekan-rekannya di lingkungan pesantren.

Seorang santri ketika dia menimba ilmu di pesantren segala bentuk tindakan dan kelakuannya menjadi tanggung jawab penuh pesantren dalam mendidik, membimbing, dan membinanya, sedangkan apabila anak sudah kembali lagi ke rumah, tanggung jawab diambil alih lagi oleh orang tuanya. Ketika sang anak pulang biasanya pihak pesantren menyertakan surat pengantar yang menyatakan bahwa "anak ini akan pulang mohon orang tua untuk mengevaluasi, membimbing. Kami titipkan kepada orang tua kembali". Hal itu sebagai bentuk tanggung jawab pesantren kepada para santrinya.

Mekanisme kepergian santri menuju rumah tinggalnya atau tempat lain di luar pesantren diatur sedemikian rupa, sehingga hanya santri-santri yang dijemputlah yang diperbolehkan meninggalkan pesantren. Itupun dilakukan dengan mekanisme perizinan yang cukup ketat. Bahkan anak yang akan pulang harus mengisi buku daftar izin kepulangan, selain dia juga diwajibkan untuk memegang kartu izin, dan surat izin dari dewan santri sebagai pemberi rekomendasi. Ketatnya aturan mengenai izin keluar masuk dilakukan untuk menjajaki hal-hal yang tidak diinginkan apalagi perempuan.

Tingginya intensitas belajar para santri, baik itu secara formal di sekolah maupun informal di pesantren menyebabkan mereka tidak memiliki banyak waktu untuk mengerjakan hal-hal lain selain belajar dan istirahat. Oleh sebab itu pihak pesantren memberikan keringanan kepada santri untuk mengurusi makan dan cuci bajunya oleh "ibu-ibuan" dan "bibi-bibian". "Ibu-ibuan" merupakan keluarga pengurus pesantren, dan dewan santri yang bertugas menyediakan makan kepada santri. Sedangkan "bibi-bibian" adalah masyarakat yang tinggal sekitar pesantren dan bertugas mencuci pakaian para santri dengan imbalan biaya. Para santri yang mondok di pesantren dipisah berdasarkan jenis kelaminnya. Asrama laki-laki (ikhwan) dan perempuan (akhwat) ditempatkan pada gedung yang terpisah di mana asrama ikhwan terdiri dari dua asrama besar yang dinamakan Al-Manba 1 dan Al-Manba 2 dan masing-masing asrama dipimpin oleh seorang Rois (pemimpin kamar). Apabila dilihat dari jumlah asrama akhwat yang ada, yaitu sebanyak 5 asrama, diperkirakan jumlah santri perempuan lebih banyak daripada santri laki-laki. Asrama akhawat ini dipimpin oleh seorang Roisah. Jumlah santri yang ditempatkan pada setiap kamar ini sekitar 10-15 orang.

Sebagai sebuah tempat, wadah ataupun lembaga, pesantren tentunya memiliki norma, aturan tentang kesopanan dan tatakrama sosial yang senantiasa diaplikasikannya dalam kehidupan seharihari. Tatakrama dalam kehidupan di pesantren dibentuk sedemikian rupa oleh pemegang kekuasaan di pesantren, dalam hal ini jajaran pimpinan pondok pesantren 
atau para ustadz dan kiai. Hal tersebut dilakukan untuk menjaga keteraturan, kedisiplinan, dan yang lebih utama adalah sebagai media pembelajaran kepada para santri untuk senantiasa menjaga sikap, perilaku dalam kesopanan sebagai bagian dari proses mereka menuntut ilmu.

Seorang santri yang memiliki amanah untuk mencari ilmu agama, apabila ingin sukses dalam mencari dan mempelajari ilmu mereka, maka seharusnya mereka mempunyai adab atau tatakrama yang berhubungan dengan diri mereka sendiri maupun yang berhubungan dengan orang lain, terlebih terhadap guru yang mengajar mereka maupun terhadap teman seperjuangan mereka di pesantren.

"Anak-anak yang akan mondok di pesantren biasanya berasal dari berbagai tempat yang memiliki latar belakang dan karakter akhlak yang berbeda-beda $^{6}$. Di pesantren inilah karakter-karakter yang berbeda-beda tersebut dibentuk berdasarkan akhlak, etika, perilaku, tatakrama, sesuai dengan akhlak yang baik dalam Islam. Dengan demikian, salah satu tugas pesantren adalah mengupayakan supaya karakter yang berbeda-beda dari para santrinya tersebut untuk dicetak agar memiliki akhlak yang baik, baik itu terhadap dirinya sendiri, kepada Allah, maupun dengan teman sebaya, teman kakak adik, keluarga, pengurus yang lebih dewasa, dan lingkungan sosialnya" 7 .

Secara umum pesantren ini memiliki misi untuk mencetak dan mendidik seluruh santrinya untuk memenuhi kriteria seorang muslimin dan muslimah yang benar-benar berkarakter, bertatakrama, dan berkepribadian islami sesuai dengan akhlakul karimah yang dikonsepkan dalam

6 Perbedaan akhlak pada setiap anak dapat dilihat secara kasat mata dari kepatuhan dan ketaatannya terhadap peraturan dan tata karma yang diberlakukan di lingkungan pesantren.

7 Wawancara dengan Eka Mulyana (Ketua Dewan Santri Pesantren Sukamanah), Januari 2017 ajaran Islam. Pesantren berusaha untuk menggembleng dan mendidik mental, dan spiritual para santrinya supaya mampu menjadi pribadi-pribadi yang baik.

\section{Tatakrama di Pesantren Sukamanah a. Pendidikan Akhlak sebagai Kurikulum Wajib}

Untuk mewujudkan misi pesantren dalam mencetak generasi yang berkepribadian dan berakhlakul karimah, maka diwujudkan dalam bentuk pembelajaran melalui mata pelajaran akidah akhlak dalam setiap tingkatan kurikulum pendidikannya. Muatan pelajaran akhlak ini hampir mencapai $80 \%$ dari keseluruhan mata pelajarannya. Artinya pendidikan akhlak tidak hanya diberikan secara tersendiri melalui mata pelajaran khusus, tetapi juga diimplementasikan dalam setiap pelajaranpelajaran yang diberikan secara implisit. Pesantren berusaha agar seluruh mata pelajaran diintegrasikan untuk membentuk perubahan sikap atau kepribadian dalam merubah tatakrama kehidupan seorang muslim.

Mata pelajaran akhlak yang diterima santri diberikan secara bertahap sesuai dengan tingkat pendidikannya. Pada tingkatan dasar Tamhidiyah atau Taman Kanak-kanak terdapat kitab akhlakul lil banin, kitab ini mengajarkan mengenai kenapa seorang anak harus mempunyai etika sejak usia dini, hal tersebut dijelaskan secara rinci oleh pengarang atau musonif kitabnya dengan bahasa yang sederhana dan bisa difahami oleh anak seusianya. Kitab tersebut juga membahas manfaat memiliki etika sejak kecil itu seperti apa, dan bagaimana dampak dari adanya manfaat bagi dirinya pribadi dan orang lain di sekitarnya. Setelah santri dapat mengaji dari kitab tersebut dan mendapatkan tambahan wawasan, mereka diharapkan dapat menyadari bahwa hidup itu tidak bisa didasarkan atas kemauan kita sendiri tapi ada batasan-batasan yang harus dipatuhi supaya terjadi harmonisasi. 
Kitab wasoyya dan taisirul khalak merupakan kitab lanjutan pada tingkatan Ibtidaiyah (MI). Wasoyya, berarti nasihatnasihat. Apabila ditelusuri secara harfiah atau bentuk katanya wasoyya berarti juga wasiat, artinya wasiat dari seorang ayah kepada anaknya mengenai bagaimana cara menjalani kehidupan yang bermartabat, bisa hidup bahagia di dunia maupun di akhirat. Dalam kitab wassoyya sering dipertegas dengan kata-kata "yaa bunnayya" yang artinya wahai anakkuwahai anakku yang terus diulang-ulang dalam kitab tersebut. Isi dan makna yang terkandung dalam kitab wassoyya, selaras dengan Al-quran surat Luqman ayat 11-19 yaitu nasihat Lukman kepada anaknya. Selanjutnya ada kitab Taisirul khalak. Kitab ini terkait dengan akhlakul karimah dan akhlakul majmumah atau akhlak baik dan akhlak jelek. Seperti tassamuf atau kejujuran lebih diperdetail lagi definisi dan manfaatnya.

Pada tingkatan selanjutnya Madrasah Tsanawiyah (MTs) dan Madrsah Aliyyah (MA) terdapat kitab Ta'lim mu'talim, kitab ini lebih mengajarkan cara belajar mengajar, fungsi ilmu untuk apa, cara santri belajar harus seperti apa, bagaimana cara mentransferkan ilmu dari guru ke santrinya, bagaimana cara ta'dzim atau hormat kepada seorang guru ataupun kepada kitab itu sendiri. Dalam kitab Ta'lim mu'talim dibahas juga bagaimana akhlak kepada guru, kakak, teman sebaya, orang tua, bahkan dengan ilmunya sendiri.

Lebih tinggi lagi terdapat kitab biddayatul hidayah untuk anak tingkatan SMA atau MA. Sedangkan untuk tingkatan dewasa ada kitab risalah muawanah dan al-hikam, itu membahas selain akhlak dengan sesama baik itu teman, guru, dan orang tua, juga membahas bagaimana akhlak dengan Allah. Lebih kepada pendekatan $u$ budiyah ${ }^{8}$.

8 Ubudiyah merupakan cara spiritual yang dilakukan oleh seseorang yang sungguhsungguh dalam beribadah kepada Alloh.
Terdapat beberapa tahapan yang harus dilalui untuk menjadi seorang santri di Pesantren Sukamanah. Pertama adalah tahapan pendaftaran, lalu taujihad/orientasi/mos. Taujihad dapat diartikan sebagai kajian untuk mengetahui arah, tujuan yang akan dicapai. Pada tahapan ini mental santri baru dikondisikan dan didoktrin sedemikian rupa supaya dapat cepat beradaptasi dengan lingkungan pesantren. Adaptasi dalam hal ini adalah penyesuaian cara hidup, cara bergaul, dan cara belajar yang kondisinya berbeda dari keseharian mereka sebelumnya. Masa taujihad ini berlangsung selama satu minggu, namun bisa ditambah apabila dimungkinkan dalam bentuk bimbingan ibadah dan bimbingan akhlak. Hal ini dilakukan untuk mempercepat proses adaptasi santri baru. Karena latar belakang lingkungan sosial santri berbeda-beda, dalam taujihad semua santri diarahkan pada satu tujuan yaitu mendapatkan ridho Allah dengan cara belajar dan mengkaji ilmu dengan cara-cara yang telah ditentukan oleh aturan pesantren. Tahapan ini juga ditujukan langkah awal untuk menetralisir pengaruh-pengaruh luar, dan untuk mengenalkan tatakrama kepada santri di lingkungan pesantren. Termasuk di dalammnya cara hidup bersahaja, mandiri, dan dewasa.

Hampir sebagian besar santri di Pesantren Sukamanah mondok atau tinggal di dalam lingkungan pesantren, namun ada beberapa yang pulang pergi yang disebut santri kalong. Santri kalong adalah sebutan bagi mereka yang berasal dari kampung-kampung sekitar pesantren yang datang hanya untuk mengikuti pengajian saja. Sesuai dengan kebijakan pesantren mereka dibebaskan dari seluruh biayabiaya.

Dalam menjalani kehidupan yang bersahaja selama di pesantren, terkadang ada saja santri yang secara mental tidak siap menghadapi lingkungan pesantren yang atmosfernya berbeda dengan 
lingkungan mereka sebelumnya. Hal inilah yang sering dirasakan oleh para pengurus pesantren, karena mereka mengetahui bahwa tidak seluruh santri datang atas kehendaknya sendiri. Sehingga sebetulnya kegiatan taujihad merupakan proses seleksi alam, di mana nanti para santri akan merasakan betah atau tidak, akan bertahan lama atau tidak dapat diketahui dari awal. Memang adakalanya beberapa santri yang mengundurkan diri karena tidak dapat bertahan dalam sistem yang telah diciptakan pesantren dengan sedemikian rupa, namun jumlahnya tidak terlalu banyak hanya satu dua orang saja, itupun dalam jangka waktu yang biasanya terjadi pada interval waktu tertentu, yaitu sebulan atau dua bulan sekali.

Untuk mencegah terjadinya hal tersebut dilakukan, diperlukan adanya komunikasi antara pihak pesantren dengan orang tua. Pihak pesantren berusaha untuk mengedukasi orang tua supaya mempercayakan sepenuhnya pengasuhan kepada pesantren tanpa harus mengkhawatirkannya secara berlebihan. Rata-rata alasan santri yang kembali pulang ke rumahnya adalah karena mereka belum bisa meninggalkan kebiasaan lamanya di rumah mereka. Kebiasaan yang memanjakan terutama santri yang masih duduk di bangku tsnawiyah, seperti makan disuapi, tidur dekat dengan ibu, serta berbagai kedekatan emosional lainnya dengan kedua orang tuanya, sangat menghambat pola adaptasi di lingkungan barunya.

\section{b. Tata Kelakuan dalam Pendidikan Akhlak}

Tata kelakukan merupakan bagian dari norma sosial yang juga biasa disebut tatakrama dalam bahasa umum. Sebagai tata kelakuan, tatakrama ini berhubungan erat dengan adab kesopanan atau sopan santun. Mengaplikasikan tatakarama dalam kehidupan sehari-hari sangat penting untuk memudahkan manusia diterima di lingkungan masyarakatnya.
Terdapat hubungan yang cukup signifikan antara pola adaptasi dan pendidikan akhlak yang dilakukan oleh Pesantren Sukamanah. Kondisi ini berimbas pada implemenatasi etika, kesopanan, dan tatakrama antara gurumurid, ataupun santri dengan para pengajar, kiai ataupun rekan sesama santri di pesantren. Etika, kesopanan, dan tatakrama yang ditonjolkan berupa sikap, perilaku, ucapan, dan bahasa tubuh, antara guru-murid. Adab-adab kesopanan dan tatakrama inilah yang senantiasa dijaga dan diatur dengan ketatnya, sehingga menjadi pembeda antara lingkungan pesantren dengan lingkungan sosial lain pada umumnya.

Sebagaimana merujuk pada pengertian tatakrama yang telah diuraikan di atas, bahwa dalam tatakrama terdapat sebuah kesepakatan yang disetujui bersama. Dengan demikian seorang santri ketika memutuskan untuk mondok di pesantren, secara langsung menyatakan dan mengikuti penerapan tata aturan dan tatakrama yang diberlakukan oleh pihak pesantren. Sebagai konsekuensinya mereka harus tunduk dan patuh terhadap aturan dan tatakrama tersebut. Di sisi lain pihak pesantren dalam menginternalisasikan nilai-nilai tatakrama, dan adab kesopanan menggunakan pendidikan akhlak sebagai media pengimplementasian tatakramanya.

Tatakrama seorang santri apabila bertemu dengan seniornya yang sudah duduk di bangku madrasah aliyah biasa mengucapkan salam atau berjabatan tangan. Begitu pula dengan seniornya yang didaulat menjadi pengurus kamar atau rois/roisah, bentuk penghormatan mereka lebih tinggi lagi dengan mencium tangan. Hal serupa juga dilakukan kepada ustadz, dewan santri, dan kiai yang ada di pesantren. Kepada mereka santri tidak hanya mengucap salam, dan mencium tangan, tetapi sikap tubuh dan ta'dzimnya juga lebih tinggi ditandai dengan berdiri apabila orang yang mereka hormati lewat 
di depannya atau mereka yang melewati orang yang dihormatinya.

Sebaliknya dari sikap dan perilaku senior kepada juniornya juga tidak berlebihan, hanya sebatas mengayomi dan bersikap respek terhadap santri junior. Para santri-santri senior senantiasa memberikan perhatian selama memang hal tersebut dibutuhkan juniornya, tidak ada kesan cuek atau tidak peduli bilamana santri junior membutuhkan bantuan dan bimbingan dari santri-santri seniornya. Mereka akan membantu semampu yang dapat mereka lakukan. Dalam pergaulan sehari-hari sikap hormat kepada santri senior ditunjukan dengan berdiri memberikan salam. Apalagi ketika datang guru atau kiai santri-santri langsung datang menyambangi dan mencium tangannya.

Begitu pula halnya dengan tatakrama pada orang tua yang dihormati, seperti para ustadz dan kiai. Tidak seperti di pesantrenpesantren tradisional lainnya yang sangat tunduk dan patuh terhadap kiainya, sehingga mengharuskan pada saat-saat tertentu para santri sungkem kepada mamak kiainya, di Pesantren Sukamanah hal tersebut tidak dilakukan. Tidak ada penghormatan berlebihan kepada mereka yang dituakan dan dihormati. Semua dilakukan dengan batas-batas kewajaran tertentu, sesuai dengan adab kesopan santunan yang dimiliki pesantren.

Sementara itu untuk menunjukkan sikap hormat secara verbal, digunakan istilah akang atau teteh untuk memanggil yang lebih tua, ataupun juga rekan sebaya. Sebaliknya sapaan santri senior kepada yang di bawahnya cukup dengan panggilan ade atau langsung menyebutkan namanya. Adapun menyebutkan kata akhi atau $u k h t i$ tidak digunakan dalam istilah pergaulan sehari-harai, hanya dilakukan ketika ada pertemuan formal atau ketika sedang ceramah keagamaan. Begitu pula dalam keseharian para santri lebih dominan mengedepankan tradisi Sunda, terutama dalam berkomunikasi mereka lebih cenderung untuk menggunakan bahasa Sunda sebagai bahasa sehari-hari mereka.
Sehingga santri yang berasal dari luar daerah Sunda, seperti Jakarta dan sekitarnya, harus beradaptasi juga dengan tradisi dan bahasa Sunda.

Dalam hal kebudayaan, hanya tradisi pencak silat saja yang masih dihidupkan dalam kehidupan pesantren, selebihnya ada di sekolah formal. Berbagai macam kesenian seperti calung, angklung, kecapi suling, dan jaipongan masih dipelajari, namun sebatas dalam kegiatan pembelajaran di sekolah. Pesantren sebagai tempat di mana anak-anak sekolah menimba ilmu di dalamnya, sangat memfasilitasi hal tersebut. Contohnya apabila santri butuh mempelajari jenisjenis alat musik tradisional seperti suling, yang harus dibawa ke pondok, hal itu tidak dilarang selama untuk tujuan pembelajaran.

Berbeda halnya dengan alat komunikasi seperti telepon seluler atau handphone sangat dilarang. Alasan pihak pesantren membatasi alat komunikasi adalah belajar dari pengalaman, karena ternyata dengan handphone pergaulan santri bisa sangat bebas berkomunikasi dengan siapapun, mudah untuk janjian atau pacaran. Pesantren sangat membatasi dan menjaga hubungan percampuran antara santri laki-laki dan santri perempuan atau yang diistilahkan dengan ikhtilat. Selain itu untuk lebih mengedepankan pesantren sebagai simbol kesederhanaan. Jadi dengan begitu siapapun mereka yang hendak tinggal di pesantren, mereka harus mengedepankan kesederhanaan dengan salah satu contohnya adalah tidak menggunakan alat komunikasi modern.

Untuk memfasilitasi komunikasi antara orang tua dengan santri disediakan khusus oleh pihak pesantren melalui bidang keamanan, yaitu berupa telepon khusus yang tidak berbasiskan telepon pintar. Seluruh santri diperbolehkan untuk menggunakan telepon tersebut apabila memang sangat membutuhkan berkomunikasi dengan orang tua atau wali nya. Sedangkan untuk mengetahui keadaan dan perkembangan dunia luar, santri 
diperbolehkan untuk mengakses komputer pada setiap hari Kamis dan Jumat sore.

Tentunya berat bagi santri menghadapi kondisi seperti ini pada awalnya, namun dengan dibiasakan disertai pemberian sanksi yang tegas dengan tidak dikembalikan lagi handphonenya untuk selamanya atau diberi sanksi diganti dengan denda yang cukup tinggi nominalnya, perlahan-lahan mereka bisa dan terbiasa.

Tatakrama dalam tataran yang telah dijabarkan di atas khususnya yang berlaku di Pesantren Sukamanah dapat dikategorikan sebagai norma sosial pada tingkatan ketiga yaitu tata kelakuan. Tata kelakuan mencerminkan sifat-sifat yang hidup dari kelompok manusia yang dilaksanakan sebagai alat pengawas, secara sadar maupun tidak sadar, oleh masyarakat terhadap anggota-anggotanya. Adab tatakrama dan sopan santun yang dijaga oleh setiap santri baik itu kepada sesamanya maupun kepada orang lain yang memiliki kedudukan lebih tinggi darinya merupakan sebuah bentuk alat pengawasan internal. Dengan adanya alat pengawasan inilah para santri dapat hidup dan bergaul dengan batasan-batasan tertentu yang sudah ditetapkan berdasarkan pengetahuan mereka dalam berakhlakul karimah. Nilainilai akhlak yang baik ini tertanam sedemikian rupa oleh pendidikan dan pengajaran yang diterimanya, sehingga tata kelakuan yang mereka lakukan senantiasa terkontrol oleh nilai-nilai tersebut.

\section{c. Tata Tertib di Pesantren Sukamanah}

Berikut ini disajikan sejumlah aturan yang harus dipatuhi seluruh santri yang mondok di Pesantren Sukamanah, yang secara formal tertulis dalam tata tertib pesantren yang terkait dengan tatakrama kesopanan dan pergaulan.

Dalam menjalankan tatakrama kesopanan, semua santri wajib memakai pakaian sesuai dengan aturan yang ditetapkan pesantren; santri laki-laki wajib berambut pendek, sopan, dan tidak diwarnai, sedangkan santri perempuan wajib menggunakan hijab tertutup, serta berperilaku sopan sesuai dengan norma kepesantrenan; setiap santri harus bersikap ramah dan sopan kepada mudarris, pengurus, keluarga, dan orang-orang yang lebuh tua serta saling menyayangi dan bekerjasama di antara seluruh penghuni pesantren; santri hanya menggunakan seragam pada jam-jam/hari-hari sekolah; Untuk meminimalisir keresahan di lingkungan pesantren, semua santri dilarang melakukan hal-hal yang dapat mengganggu ketentraman orang lain; proses perizinan harus ditempuh oleh santri yang bermaksud keluar komplek pesantren; diwajibkan untuk meminta izin dengan ketentuan sebagai berikut :

Bagi santri putra yang berkehendak keluar pesantren diwajibkan meminta izin kepada rois dan putri kepada dewan santri serta roisah; bagi santri yang memiliki keperluan pulang, santri wajib meminta izin kepada pengurus dewan santri dengan membawa buku izin untuk ditandatangani dan setelahnya melapor kepada rois/roisah; Santri yang bermaksud pulang, diharapkan untuk meminta restu dan doa kepada sesepuh/pimpinan pesantren atau dewan guru yang lain; Buku izin pulang harus ditandatangani oleh orang tua/wali dan menyerahkannya kembali buku izin tersebut kepada rois/roisah sekaligus mengisi paraf pada bagian kembali dalam buku agenda pulang santri; Khusus bagi santri putri, tidak diperkenankan pulang sebelum ada jemputan dari orang tua/wali santri dengan membawa kartu jemputan pulang.

Sedangkan untuk menerapkan tatakrama dalam pergaulan, Pesantren Sukamanah menerapkan aturan sebagai berikut: semua santri dilarang melakukan hubungan di luar batas dengan lawan jenis dan atau pihak luar; semua santri dilarang mengunjungi asrama lawan jenis tanpa izin dewan santri dan rois/roisah; semua santri harus tetap tinggal di dalam lingkungan pesantren; selain kelompok-kelompok 
telah dibentuk oleh pesantren yang berupa jema'ah, santri tidak diperkenankan membentuk kelompok lain; para santri dilarang mengajarkan dan atau mempelajari ilmu yang memadaratkan atau tidak bermanfaat bagi dirinya dan orang lain.

\section{Pendidikan Akhlak sebagai Dasar Pembentukan Karakter}

Pendidikan akhlak pada dasarnya memuat aturan-aturan hidup yang mengatur tata kelakuan antara sesama manusia dengan ilmu agama sebagai intinya. Aturan-aturan agama yang bersumber baik itu dari Al-Qur'an dan AlHadist diimplementasikan dalam pendidikan akhlak, khususnya kitab-kitab akhlak secara bertahap pada setiap tingkatan pendidikan santri di Pesantren Sukamanah.

Melalui kitab-kitab akhlak ini para santri dididik menjadi manusia yang memiliki kecerdasan spiritual dalam bertingkah laku. Kecerdasan spiritual ini dibutuhkan untuk membangun sebuah kepribadian yang utuh, supaya seseorang memiliki kemampuan adaptif untuk membangun diri dan jiwanya. Untuk mencapai tujuan tersebut diperlukan adanya berbagai kegiatan positif, sehingga seseorang mampu mengendalikan dan menyelesaikan berbagai persoalan dengan baik dalam situasi dan kondisi yang sulit sekalipun. Pendidikan akhlak bukan satusatunya unsur yang dapat menjadi penentu dimilikinya kecerdasan spiritual bagi seorang santri, namun sangat menentukan, karena melalui pendidikan akhlak sikap dan perilaku santri diasah sedemikian rupa supaya mampu menjadi pribadi yang lebih sabar, bijaksana, dan taat dalam bergaul.

Pembelajaran akidah akhlak dilakukan oleh pesantren secara bertahap sesuai dengan kemampuan intelektual serta psikologis santri. Semakin dewasa usia dan semakin tinggi kemampuan santri menyerap ilmu-ilmu agama maka kurikulum pendidikan akhlak yang diajarkan pun semakin tinggi. Tinggi dalam pengertian ini berarti materi pembelajarannya semakin kompleks serta pendalaman materinya dilakukan secara lebih intensif untuk memperoleh pemahaman yang baik dan kaffah mengenai konsep-konsep akidah dan akhlak.

Sebagai sebuah mata ajar, pendidikan akhlak tidak saja mengatur hubungan bagaimana seharusnya manusia berperilaku yang baik terhadap Allah, tetapi juga memberikan pembelajaran mengenai konsep-konsep hubungan antara manusia dengan manusia lainnya. Termasuk juga hubungan antargolongan atau kelompok manusia yang didasarkan pada strata maupun status yang dibentuk secara sosial. Dengan kata lain pendidikan akhlak memiliki cakupan yang cukup komprehensif sebagai ilmu perilaku.

Pendidikan akhlak dengan berbagai konsep dan teorinya memberikan modal bagi konsep berperilaku para santri dalam bersikap dan bertingkah laku yang baik. Adapun praktik dari implementasi akidah akhlak diperoleh santri dari peraturan dan tata tertib yang diberlakukan oleh pesantren. Aturan-aturan yang ketat dengan sanksi disiplin yang diterapkan apabila terjadi pelanggaran, merupakan contoh praktis dari implementasi akidah akhlak yang memiliki visi spiritual. Tata tertib yang diberlakukan oleh pesantren sebagai lembaga pendidikan bertujuan untuk membentuk kepribadian, kedisiplinan, dan kemandirian para santri saat menuntut ilmu di pesantren. Oleh karenanya tata tertib tersebut juga mengandung unsur paksaan yang sejalan dengan konsep tata kelakuan sebagai alat untuk memaksa para anggotanya untuk melakukan suatu perbuatan dan di lain pihak melarang perbuatan-perbuatan tertentu.

Adab kesopanan dalam pergaulan secara formal tertulis dalam tata tertib dan disepakati bersama sebagai sebuah aturan main yang harus ditaati dan dipatuhi oleh semua pihak, khususnya para santri. Hal tersebut juga sesuai dengan konsep norma 
yang mengatur mengenai kesopanan dalam pergaulan, dan tata krama merupakan implementasi praktis dari norma kesopanan tersebut.

Sebagai sebuah implementasi praktis dari norma kesopanan, tatakrama dianggap sebagai alat yang ampuh dalam mengatur perilaku para santri sesuai dengan apa yang diinginkan atau diharapkan. Pada tataran lain, karakter baik yang diharapkan muncul dari dalam diri seorang santri dapat dibentuk dan diupayakan oleh tatakrama. Tatakrama memiliki metode-metode pendidikan yang berguna untuk mendidik perilaku dan kesopanan para santri, sehingga mereka dapat bersikap dan bertindak sesuai dengan aturan yang diharapkan.

Harapan-harapan terhadap nilai-nilai kepatuhan dan ketaatan ini tentunya didasarkan pada aturan tertulis dari sebuah pembelajaran akidah akhlak yang diberikan secara formal. Pendidikan akhlak dapat dikatakan sebagai sebuah faktor yang mampu membawa perubahan, sehingga diharapkan mampu membentuk karakter dalam diri dan jiwa para santri. Harapan tinggi disandarkan pada para santri sebagai generasi muda yang kelak akan mengemban tugas mulia sebagai calon-calon pemimpin bangsa, disamping itu institusi pesantren juga memiliki tugas yang cukup berat, yaitu dapat mencetak dan membangun karakter para santri yang memiliki nilai-nilai karakter luhur dan mulia. Salah satu upaya untuk mewujudkan hal tersebut adalah dengan membekali para santri dengan pendidikan akhlak dan norma kesopanan.

\section{PENUTUP}

Pesantren sebagai lembaga pendidikan berbasis agama memiliki visi dan misi yang sama seperti halnya lembaga pendidikan konvensional lainnya guna mencerdaskan kehidupan bangsa. Penekanan pada ilmu keagamaan yang lebih banyak dibandingkan pendidikan konvensional, menjadikan pesantren memberikan porsi yang lebih besar terhadap pendalaman nilai-nilai spiritual. Namun demikian baik lembaga pendidikan konvensional maupun pesantren sepakat untuk bersama-sama menanamkan pendidikan karakter sebagai bekal bagi generasi mendatang untuk menjadi diri dengan kepribadian yang lebih baik secara sosial, mental dan spiritual.

Pendidikan akhlak merupakan salah satu mata pelajaran di pesantren yang dianggap dapat memberikan pembelajaran nilai-nilai kepribadian yang didasarkan pada konsep ilmu agama. Pendidikan akhlak sebagai sebuah konsep dan teori kemudian diimplementasikan dalam bentuk praktisnya melalui tata tertib dan tatakrama yang harus ditaati oleh seluruh santri yang mondok di pesantren. Tata tertib pesantren sebagai implementasi pendidikan akhlak, yang di dalamnya terdapat adab-adab kesopanan dan pergaulan, serta tatakrama yang mengatur etika pergaulan antar dan sesama santri maupun antara santri dengan mereka yang dituakan, tentunya memiliki nilai-nilai yang sangat baik dalam membentuk karakter dan kepribadian santri. Sehingga diharapkan dengan terinternalisasinya tata tertib dan tatakrama, terinternalisasi pula norma-norma sosial yang lebih khusus lagi norma kesopanan sebagai salah satu elemen yang dapat membentuk karakter yang baik bagi para santri.

Secara umum pendidikan akhlak yang didasari oleh nilai-nilai keagamaan dan dogma religius diharapkan mampu meningkatkan keimanan, ketakwaan, dan perilaku serta karakter yang baik bagi para santri. Hal tersebut tentunya sejalan dengan tujuan utama dari sebuah kurikulum pembelajaran pendidikan akhlak. Lebih khusus dan akan lebih berarti lagi kiranya dalam kerangka sosialisasi, pendidikan akhlak diperkaya dengan berbagai nilai-nilai sosial budaya yang tentunya memberikan nilai tambah bagi pendalaman dan internalisasi pendidikan karakter.

Sebaliknya di lembaga-lembaga pendidikan kovensional penekanan lebih, 
kiranya dapat diarahkan pada pendidikan karakter berakhlak dan berbudi, yaitu sebuah metode pendidikan karakter yang mengadopsi nilai-nilai religiusitas dan kearifan budaya. Hal ini dilakukan supaya implementasi pendidikan karakter lebih optimal.

\section{DAFTAR SUMBER}

\section{Makalah, Laporan Penelitian, Skripsi, Tesis, dan Jurnal}

Kumalasari, Dyah. "Pendidikan Karakter Berbasis Agama" dalam Jurnal Penelitian Pendidikan Vol. 14 No. 2 Tahun 2012. Hlm. 716-728.

Munawar, Risaman. 2013. Pendidikan Karakter dalam Pembelajaran Akidah Akhlak di MTs Negeri Godean. Skripsi. Yogyakarta: UIN Sunan Kalijaga.

Novitasari, Desi. 2016. Implementasi Pendidikan Karakter Berbasis Al-Qur'an di SD IT Luqman AlHakim Internasional. Tesis. Yogyakarta: UIN Sunan Kalijaga.

Rahmadi, Mamat. "Pengelolaan Pendidikan Berbasis Islam" dalam Jurnal Adminisrasi Pendidikan Vol. 21 No.1 Tahun 2014. Hlm. 1-16.

Rahman, Amri dan Dulsukam Kasim. "Pendidikan Karakter Berbasis Al-Quran : Upaya Menciptakan Bangsa yang Berkarakter" dalam Jurnal Al-Ulum Vol. 14 No.1. Juni 2014. Hlm. 247-268.

Shodiq. M. "Pesantren dan perubahan Sosial" dalam Jurnal Falasifa Vol. 2 No. 2. September 2011. Hlm. 107-118.

Triwulandar, Desi. 2015.

Penerapan Pendidikan Karakter dalam Meningkatkan Akhlak di Homeschooling Grup SD Khoiu Ummah 20 Malang. Skripsi. Malang: UIN Maulana Malik Ibrahim.

\section{Buku}

Dhofier, Zamakhsyari. 1982.

Tradisi Pesantren : Studi tentang Pandangan Hidup Kyai. Yogyakarta: LP3ES
Gunawan, Heri. 2012.

Pendidikan Karakter, Konsep dan Implementasi. Bandung : Alfabeta.

Samani, Muchlas dan Hariyanto. 2013. Konsep dan Model Pendidikan Karakter. Bandung: Remaja Rosdakarya.

Schaefer, Richard T. 2012. Sosiologi. Jakarta: Salemba Humanika.

Setiadi, Elly M. dan Usman Kolip. 2011. Pengantar Sosiologi. Pemahaman Fakta dan gejala Permasalaha Sosial: Teori, Aplikasi, dan Pemecahannya. Jakarta: Kencana.

Simatupang, Lono Lastoro., Mudjijono, Nurdiyanto, Naely Himami, Carolina Retmawati, Bagus Suharjo, Bahari. 2012. Pendidikan Karakter Berbasis Pendidika Seni Budaya di Kota Surakarta. Jogjakarta: BPNB Jogjakarta dan FIB UGM.

Soekanto, Soerjono. 2013. Sosiologi Suatu Pengantar. Jakarta: Rajawali Press.

Speadley, James P. 1997. Metode Etnografi. Yogyakarta: Tirta Wacana Yogya.

Qomar, Mujamil. 2005. Pesantren. Jakarta: Erlangga.

Ziemek, Manfred. 1986. Burche B. Soenjojo (Translator).

Pesantren dalam Perubahan Sosial. Jakarta: P3M (Perhimpunan Pengembangan Pesantren dan Masyarakat)

\section{Internet}

Al Musawa, Sayid Musa. 2016. Darut Taqrib Jepara. Pentingnya Pendidikan Akhlak dalam Kehidupan dalam http://www.daruttaqrib.org/berita/2016/10/05/pendidikanakhlak-adalah-solusi-menyelamatkanbangsa-dan-dunia/. Diakses tanggal 11 Juli 2018.

Utama, Arya. 2010. Hubungan Antara SQ, EQ, dan $I Q$. dalam https://ilmupsikologi.wordpress.com/2010/ 02/18/hubungan-antar-sq-eq-dan-iq/. Diakses tanggal 16 November 2017. 